\title{
Coastal groundwater discharge - an additional source of phosphorus for the oligotrophic wetlands of the Everglades
}

\author{
René M. Price \\ Southeast Environmental Research Center and Department of Earth and Environment, Florida International University, \\ pricer@fiu.edu \\ Peter K. Swart \\ Rosenstiel School of Marine and Atmospheric Sciences, Marine Geology and Geophysics, University of Miami \\ James W. Fourqurean \\ Department of Biological Sciences and Southeast Environmental Research Center, Florida International University, \\ fourqure@fiu.edu
}

Follow this and additional works at: https://digitalcommons.fiu.edu/fce_lter_journal_articles

\section{Recommended Citation}

Price, R.M., P.K. Swart, J.W. Fourqurean. 2006. Coastal groundwater discharge - an additional source of phosphorus for the oligotrophic wetlands of the Everglades. Hydrobiologia 569(1): 23-36.

This material is based upon work supported by the National Science Foundation through the Florida Coastal Everglades Long-Term Ecological Research program under Cooperative Agreements \#DBI-0620409 and \#DEB-9910514. Any opinions, findings, conclusions, or recommendations expressed in the material are those of the author(s) and do not necessarily reflect the views of the National Science Foundation. This work is brought to you for free and open access by the FCE LTER at FIU Digital Commons. It has been accepted for inclusion in FCE LTER Journal Articles by an authorized administrator of FIU Digital Commons. For more information, please contact dcc@fiu.edu, jkrefft@fiu.edu. 
16

17 This paper has not been submitted elsewhere in identical or similar form, nor will it be during the

18 first three months after submission to Hydrobiologia.

19

20 Key Words

21 Coastal groundwater discharge, phosphorus, Everglades

\section{Coastal Groundwater Discharge -}

\section{an additional source of phosphorus for the oligotrophic wetlands of the Everglades}

\author{
René M. Price ${ }^{1}$, Peter K. Swart ${ }^{2}$ and James W. Fourqurean ${ }^{3}$
}

1. Department of Earth Sciences and Southeast Environmental Research Center, Florida International University, Miami, FL 33199 USA. 305-348-3119, pricer@fiu.edu

2. Rosenstiel School of Marine and Atmospheric Sciences, Marine Geology and Geophysics, University of Miami, Miami, FL 33149

3. Department of Biological Sciences and Southeast Environmental Research Center, Florida international University, Miami, FL 33199

(8)

19

20 Key Words

Coastal groundwater discharge, phosphorus, Everglades 


\section{Abstract}

2 In this manuscript we define a new term we call Coastal Groundwater Discharge (CGD),

3 which is related to submarine groundwater discharge (SGD), but occurs when seawater intrudes

4 inland to force brackish groundwater to discharge to the coastal wetlands. A hydrologic and

5 geochemical investigation of both the groundwater and surface water in the southern Everglades

6 was conducted to investigate the occurrence of CGD associated with seawater intrusion. During

7 the wet season, the surface water chemistry remained fresh. Enhanced chloride, sodium, and

8 calcium concentrations, indicative of brackish groundwater discharge, were observed in the

9 surface water during the dry season. Brackish groundwaters of the southern Everglades contain

101 to $2.3 \mu \mathrm{M}$ concentrations of total phosphorus (TP). These concentrations exceed the expected

11 values predicted by conservative mixing of local fresh groundwater and intruding seawater,

12 which both have $\mathrm{TP}<1 \mu \mathrm{M}$. The additional source of TP may be from seawater sediments or

13 from the aquifer matrix as a result of water-rock interactions (such as carbonate mineral

14 dissolution and ion exchange reactions) induced by mixing fresh groundwater with intruding

15 seawater. We hypothesize that CGD maybe an additional source of phosphorus (a limiting

16 nutrient) to the coastal wetlands of the southern Everglades. 


\section{Introduction}

All coastal aquifers with a hydraulic connection to the sea are susceptible to seawater

3 intrusion (Bear et al., 1999). The interface between freshwater and seawater in coastal aquifers

4 was first identified by (Du Commun, 1828), half a century earlier than the more widely cited

5 Ghyben-Herzberg principle (Ghyben, 1888;Herzberg, 1901). A systematic study of seawater

6 intrusion in the 1950s in south Florida formed a set of benchmark papers on the subject (Cooper,

7 1959; Kohout, 1960; 1964). The most significant finding of these studies was the recognition

8 that the freshwater-seawater interface was not sharp as described by the Ghyben-Herzberg

9 principle, but formed a zone of mixed water composition termed by many in the field as a

10 'mixing zone' (Fig. 1a; Back et al., 1986; Price \& Herman, 1991). Brackish water in this mixing

11 zone is circulated along with the freshwater to the sea (Cooper, 1959). If the groundwater

12 discharge occurs beneath overlying marine or estuarine waters it is termed submarine

13 groundwater discharge (SGD; Younger, 1996; Fig 1a). However, the position and extent of the

14 mixing zone and the flux of its associated brackish groundwater discharge is governed by many

15 factors such as rainfall, groundwater withdrawals, irrigation and evapotranspiration on the

16 freshwater side, with tides, waves, and changes in sea level on the seawater side (Kohout, 1960;

17 Bear et al., 1999). Along many of the worlds developed coastlines, the combined effects of

18 increased groundwater withdrawals and sealevel rise results in enhanced seawater intrusion into

19 the freshwater coastal aquifers (Konikow \& Reilly, 1999), thereby shifting the discharge of

20 brackish groundwater inland (Fig. 1b). We wish to define a new term, coastal groundwater

21 discharge (CGD) to describe the discharge of brackish to saline groundwater to coastal areas

22 including coastal wetlands and streams (Fig. 1b). 
The discharge of this brackish groundwater can have a significant impact on the ecology

2 of dominantly freshwater coastal wetlands and streams. CGD has the potential to alter the

3 salinity of wetland soils and surface waters, to be a source of water, and to deliver dissolved

4 constituents like nutrients and dissolved toxins. Such discharge also can be an important

5 determinant of the productivity of coastal systems, as they are often nutrient limited and

6 groundwater tends to be enriched in nitrogen and phosphorus compared to oligotrophic surface

7 waters.

8 The potential for brackish groundwater discharge to the surface water of the Everglades

9 as evidenced by a comparison of groundwater and surface water levels was presented earlier

10 (Price et al., 2003). The objective of this paper is to provide geochemical evidence of the

11 discharge of brackish groundwater to the overlying surface water of the coastal Everglades.

12 Furthermore, this paper demonstrates that the brackish groundwater contains elevated

13 concentrations of phosphorus (P). Phosphorus limits primary producer biomass, animal biomass,

14 the structure of the primary producer community, the structure of the microbial community and

15 the structure of animal community of the coastal Everglades (Armitage et al., 2005; Armitage et

16 al., this issue; Gil et al., this issue). We propose that the enhanced productivity of the freshwater-

17 marine ecotone of the coastal Everglades as compared to either freshwater or marine end-

18 members maybe fueled by the P delivered by CGD.

\section{Site Description}

21 The Everglades occupies most of the south Florida peninsula and discharges into Florida

22 Bay and the Gulf of Mexico (Fig. 2). The topography across the Everglades is extremely flat,

23 and contributes to an exceptionally low hydraulic gradient $\left(5 \times 10^{-5}\right)$ and poorly defined 
1 watershed boundaries. The Surficial Aquifer System (SAS) in south Florida consists of Miocene

2 to Holocene age siliclastic and carbonate sediments and varies in thickness from $50 \mathrm{~m}$ to $82 \mathrm{~m}$

3 (Fish \& Stewart, 1991; Reese \& Cunningham, 2000). The Biscayne Aquifer forms the top of the

$4 \quad$ SAS and is the principal water supply for human development in South Florida. Its thickness

5 increases across the study site in a southeasterly direction from a feather edge in northwestern

6 Shark Slough to over $65 \mathrm{~m}$ thick along the southeastern coastline (Fish \& Stewart, 1991). The

7 Biscayne Aquifer is one of the most productive karst aquifers in the world with measured

8 transmissivities in excess of 30 million $\mathrm{m}^{2} \mathrm{yr}^{-1}$, and estimated hydraulic conductivity between 1.5

9 and 4.5 million $\mathrm{m} \mathrm{yr}^{-1}$ (Fish \& Stewart, 1991).

10 On average the Royal Palm Ranger station located in the Everglades receives $140 \mathrm{~cm}$ of

11 rain a year (30-year average from 1971 to 2000) with most occurring in the summer months from

12 mid-May through mid-October (Southeast Regional Climate Center, sercc@dnr.state.sc.us ).

13 Despite the high hydraulic conductivity of the Biscayne Aquifer and the high rainfall rate in

14 south Florida, there is significant intrusion of seawater into the SAS along its coastline,

15 particularly along the southern Everglades. The low topographic relief of the region contributes

16 to its susceptibility to seawater intrusion, particularly in response to sea level rise. Futhermore,

17 most of the water which once flowed naturally from Lake Okeechobee in central Florida

18 southward through ENP and into Florida Bay and the Gulf of Mexico, has been diverted away

19 from ENP via a complex system of canals, levees, and water control structures (Light \& Dineen,

20 1994). Seawater intrusion into the Biscayne Aquifer along the southern Florida Peninsula was

21 first documented in 1940 by Parker et al.(1955). The onset of seawater intrusion was attributed

22 to lowering of groundwater levels in the Biscayne Aquifer as a result of construction of an

23 extensive system of canals in the 1920s and 1930s designed to drain surface water from Lake 
1 Okeechobee and the Everglades to the ocean. Construction of additional canals combined with

2 periodic drought conditions resulted in increasing the extent of seawater intrusion in the

3 Biscayne Aquifer from 1904 to 1990 (Parker et al., 1955; Klein \& Waller, 1985; Sonenshein \&

4 Koszalka, 1996). No significant increase in seawater intrusion occurred in the area between

51990 and 1995 (Sonenshein, 1997). An aerial resistivity survey of shallow groundwater

6 conditions confirmed that seawater intrusion into the Biscayne Aquifer occurs along the entire

7 southern and western coastlines of the southern Everglades (Fitterman et al., 1999).

9 Methods

10 Geochemical Investigation

11 Data presented in this paper was compiled from two investigations, one conducted 12 between 1997 and 1999, and the other conducted during the summer of 2003. Between 1997 and 13 1999, a total of 45 groundwater wells (Fig. 3) were sampled on an approximately monthly basis.

14 These wells were organized into clusters of 1 to 4 wells with finished depths ranging from 2 to

$1560 \mathrm{~m}$ within the SAS and were completed by either the USGS (Fish and Stewart, 1991;

16 Fitterman, 1999) or the National Park Service. Most of the wells completed by the USGS

17 contained and some wells completed just for this investigation by the National Park Service

18 consisted of PVC pipe that was 2.5 to $5.0 \mathrm{~cm}$ in diameter with the bottom $2 \mathrm{~m}$ or less screened

19 for water collection. To prevent the exchange of surface water into the groundwater well, the

20 annulus surrounding the PVC pipe was sealed at the land surface with a bentonite/cement

21 mixture, and then the PVC pipe was capped. Pre-existing wells completed by the National Park

22 Service contained a $7 \mathrm{~cm}$ to $15 \mathrm{~cm}$ diameter metal surface casing that was between 1 to 2 meters 
1 long, with the remainder of the well left as an open borehole. More detailed description of the

2 wells and their locations can be found in Price (2001).

3 Prior to sampling, all wells were purged of at least three well volumes. Surface water

4 was collected at 23 sites in conjunction with the groundwater wells or from the canals that border

5 ENP (Fig. 3). Both groundwater and surface water samples were filtered in the field and stored

6 at $4^{0} \mathrm{C}$ until analyzed. Bottles collected for cations were acidified to a $\mathrm{pH}$ of less than 2 . The

$7 \mathrm{pH}$, specific conductance and/or salinity, and temperature were recorded at the time of sample

8 collection using an Orion $\mathrm{pH}$, and $\mathrm{S} / \mathrm{C} / \mathrm{T}$ meter, respectively. Major cations (calcium,

9 magnesium, sodium and potassium) and anions (chloride and sulfate) were determined by ion

10 chromatography on a Dionex 120 . Total alkalinity was determined by acid titration according to

11 the Gram method. A total of 1685 water samples were analyzed. A detailed description of the

12 methods for this investigation can be found in Price (2001).

13 During the summer of 2003, 14 of the groundwater wells and 9 surface water samples

14 were sampled across the seawater-freshwater mixing zone in the southern Everglades for TP

15 (Table 1). To reduce the exposure of anoxic groundwater to oxygen during sampling,

16 groundwater samples were collected directly into acid-washed, evacuated blood collection tubes

17 that were first flushed with nitrogen gas. Samples were processed for TP using colorimetery

18 following dry-oxidation/acid hydrolysis methods (Solorzano \& Sharp, 1980) within 1 to 5 days

19 of sample collection. A total of 23 water samples were analyzed for TP (Table 1).

\section{Water Chemistry}

22 Specific conductance measured in all of the water samples varied from 100 and 36,900

$23 \mu \mathrm{S} \mathrm{cm}^{-1}$ while salinity varied from 0 to $27.4 \mathrm{psu}$, with both specific conductance and salinity 
1 increasing towards the coastline. During most times of the year, surface water salinities in

2 southern Taylor Slough and the C-111 basin were below $1 \mathrm{psu}$, but increased above a value of 1

3 during three times during the study period, in March and April 1997, in July 1998, and again in

4 April and May 1999 (Fig. 4). Surface water salinity was most variable in the southern reaches of

5 Shark Slough, particularly at Tarpon Bay and Canepatch (Fig. 4). For most groundwater wells,

6 there was no discernable trend in salinity between 1997 and 1999 (Fig. 5). Goundwater salinity

7 in the C-111 basin well EP8A was the most variable (Fig. 5).

8 A Piper diagram provided geochemical evidence of brackish groundwater discharge to

9 the surface water (Fig. 6). Surface water of the Everglades is most often characterized as a

10 calcium-bicarbonate type water, typical for water in contact with limestone. The underlying

11 groundwater, at site EP8A located within the mixing zone in the C-111 basin had salinity of 13.7

12 psu at a depth of $7.6 \mathrm{~m}$ and was dominated by sodium and chloride ions (Fig. 6). During four

13 sampling events in the dry-season, surface water at EP8A had elevated concentrations of sodium

14 and chloride relative to the other ions and these samples plot along a mixing line between the

15 freshwater and the underlying brackish groundwater. Enhanced sodium and chloride signatures

16 were also observed in the surface waters at sites E146 in Taylor Slough at RB-1 in Shark Slough

17 during the dry-season.

18 The mean concentrations of the cations and anions in the water samples were plotted

19 against their percent seawater composition (assuming chloride to be conservative) and compared

20 to a seawater mixing line. Calcium was enriched relative to the seawater dilution line in all

21 groundwaters containing greater than 5\% seawater (Fig. 7). Surface waters collected from

22 Canepatch and Tarpon Bay fall along the seawater dilution line, while calcium concentrations of

23 some surface waters collected at E146, EP8A, and RB-1 are enriched in calcium compared to the 
1 seawater dilution line (Fig. 8). Sodium concentrations in the surface waters and groundwaters

2 plotted along the seawater mixing line, indicating that sodium behaved conservatively upon

3 mixing with seawater. Potassium concentrations in most groundwaters plotted below the

4 seawater mixing line indicating that potassium is not conservative in the groundwater upon

5 mixing with seawater. Magnesium concentrations in both surface waters and groundwaters plot

6 along the seawater mixing line with a few groundwaters falling below the line. Similarly, sulfate

7 in most of the groundwaters and surface waters fell along the seawater mixing line, but sulfate

8 concentrations in a few groundwaters were lower than expected with seawater mixing indicating

9 sulfate is not conserved.

10 Ambient surface water concentrations of TP in the fresh waters of the Everglades were

11 extremely low and ranged from 0.16 to $0.45 \mu \mathrm{M}$ (Table 1 ). Concentrations of TP in the

12 groundwaters were consistently higher than the surface water at 0.5 to $2.3 \mu \mathrm{M}$. There was a

13 direct relationship between TP with salinity in the groundwater (Fig. 9).

\section{Discussion}

\section{Seawater Intrusion}

17 High concentrations of sodium and chloride along with salinity measurements in some

18 groundwater wells confirm the presence of seawater intrusion into the SAS along the coastline of

19 ENP (Fig. 3.). The 5 psu salinity contour line depicted on Fig. 3 is coincident with the position

20 of the seawater intrusion as determined by aerial resistivity (Fitterman et al., 1999). Contrary to

21 the aerial resistivity results that suggest a relatively sharp seawater intrusion front boundary

22 (Fitterman et al., 1999), the salinity of the groundwater wells measured in this study suggest a

23 wide brackish groundwater zone varying between 6 to $25 \mathrm{~km}$ wide. The landward extent of 
1 seawater intrusion extends the farthest inland in Shark Slough (25 to $28 \mathrm{~km}$ ) most likely due to

2 tidal action in the Gulf of Mexico. The Gulf of Mexico experiences a mixed semi-diurnal tide

3 with a maximum tidal range of $2.28 \mathrm{~m}$ at the mouth of the Shark River. Tidal forces aid in the

4 dispersion of salts along the interface of a seawater intrusion (Moore, 1999).

Seawater intrusion in the C-111 basin was found to extend 6 to $10 \mathrm{~km}$ landward from the

6 coastline, approximately coincident with the placement of the C-111 canal. Variations in

7 shallow groundwater salinity in wells located south of the C-111 canal indicate that the extent of

8 seawater intrusion in this area can vary on a monthly to seasonally basis. Tidal forces in

9 northeast Florida Bay are weak due to a dampening of the Gulf of Mexico tides by the many

10 shallow mud banks across Florida Bay. However, passing storm fronts and changes in wind

11 direction can result in changes in water levels up to $30 \mathrm{~cm}$ (Fourqurean \& Robblee, 1999). Low

12 water levels caused by dry season conditions and southerly winds can drive seawater from

13 Florida Bay into the southern creeks of the C-111 Basin (Hittle et al., 2001). Salinity increases

14 in the surface waters of the C-111 canal and southern marshes during the end of the dry seasons

15 in 1997 and 1999 (Fig. 4) are most likely in response to lowered water levels. In 1997, the

16 groundwater salinity in wells EP8A increased markedly from near 1 to above 10, and remained

17 high throughout 1998 and into 1999. This increase in groundwater salinity followed a spike in

18 the surface water salinity occurring at the end of the dry season in 1997 and is most likely in

19 response to lowered water levels during that time. The subsequent year long increase in

20 groundwater salinity of the $\mathrm{C}-111$ basin suggests that landward advancement of seawater

21 intrusion within the SAS is slow compared to that observed in the surface water. The drops in

22 salinity of the groundwater in EP8A in May and July 1999 may signify a slight seaward retreat

23 of the seawater intrusion in the SAS within the C-111 basin. The landward extent of seawater 
1 intrusion in Taylor Slough is about 10 to $14 \mathrm{~km}$ inland (Fig. 3), intermediate between that of the

2 C-111 basin and Shark Slough. The salinity of groundwater in the E-146 wells did not vary

3 markedly throughout the study period (Fig. 5), suggesting that the position of the seawater

4 intrusion front in Taylor Slough may be more stable than observed in the C-111 basin.

5 24 influenced.

\section{Evidence of CGD}

During times of low water levels, the surface water at EP8A (as well as at E146 and RB1) exhibited a brackish signature (Fig. 6). There are two potential sources for the observed seawater mixture at these surface water sites: 1) surface seawater from Florida Bay or the Gulf of Mexico moving inland with the lowering of water levels, or 2) the discharge of brackish groundwater. That these sites are approximately 6 to $25 \mathrm{~km}$ inland of the coastline and coincident with the position of the seawater intrusion in the shallow portion of the SAS (Fig. 3) suggests that brackish groundwater is the source of the seawater signature.

Elevated concentrations of calcium in the surface waters also suggest a brackish groundwater source as opposed to surface seawater from Florida Bay or the Gulf of Mexico moving inland in response to the lowering of water levels (Fig. 8). If surface seawater flowing inland from the marine bays was the source of the brackish signatures in the surface waters, then the surface water concentrations of calcium would fall along a seawater dilution line produced from mixing of fresh Everglades waters and surface seawater. In fact, mean calcium concentrations of surface waters from Tarpon Bay and Canepatch fall along a seawater mixing line indicating that surface waters at these sites do receive surface seawater from the Gulf of Mexico (Fig. 7). This result is expected since surface water levels at these sites are tidally 
Close inspection of calcium concentrations of individual surface water samples collected

2 from the surface water at sites E146, EP8A, and RB-1 reveal elevated concentrations of calcium

3 relative to the seawater dilution line in samples containing greater than 1 percent seawater (Fig.

4 8). The elevated calcium concentrations in the surface waters is a result of mixing with the

5 underlying brackish groundwater that also has elevated calcium levels as compared to seawater

6 mixing. The excess calcium in the brackish groundwaters relative to the seawater mixing line is

7 as high as $9 \mathrm{mM}$ with an average of $4.1 \pm 3.5 \mathrm{mM}$. The excess calcium concentrations are most

8 likely the result of dissolution of calcium carbonate minerals from the aquifer matrix.

\section{Phosphorus}

11 Ambient surface water TP concentrations in the fresh waters of the Everglades range

12 from 0.15 to $0.45 \mu \mathrm{M}$ (Table 1). Median TP concentrations in marine surface waters of

13 northeastern Florida Bay and the Gulf of Mexico are $0.25 \mu \mathrm{M}$ and $0.58 \mu \mathrm{M}$, respectively (Boyer

14 et al., 1999). Concentrations of TP in the groundwater underlying the coastal wetlands of the

15 Everglades range from 0.5 to $2.3 \mu \mathrm{M}$ and are consistently higher than either surface freshwater or

16 surface seawater; TP also shows a direct relationship with salinity (Fig 9). Fresh groundwater

17 TP concentrations tend to be less than $1 \mu \mathrm{M}$ (Table 1). Conservative mixing of fresh

18 groundwater having TP concentrations of less than $1 \mu \mathrm{M}$ with surface seawater from Florida Bay

19 and/or the Gulf of Mexico also having TP concentrations of less than $1 \mu \mathrm{M}$ can not produce the 1

20 to $2.3 \mu \mathrm{M}$ concentrations of TP observed in the brackish groundwater. An additional source of

21 phosphorus is needed.

22 Given that the seawater intrusion from Florida Bay must first pass through the underlying

23 sediments before entering the aquifer, then the sediments could be a source of phosphorus for 
1 saline groundwaters. Phosphorus concentrations in the sediment porewaters in the region are

2 orders of magnitude higher than the concentrations of phosphorus in the overlying surface waters

3 because of the remineralization of organic matter in the sediments and the trapping of inorganic

4 phosphorus by sorption on calcium carbonate particles. The solid aquifer matrix can also be a

5 source of phosphorus. Phosphorous may exist either as phosphorus minerals (such as apatite)

6 within the aquifer material, or may be adsorbed onto the particle surfaces. Areas of seawater

7 intrusion are known geochemically active regions particularly in carbonate aquifers, where

8 carbonate mineral dissolution (Back et al., 1986) and ion exchange (Sivan et al., 2005) are

9 important. Both of these processes can lead to a release of phosphorus from the aquifer matrix to

10 the groundwater. The excess calcium concentrations observed in the brackish groundwaters (Fig.

11 7) indicates that carbonate mineral dissolution is occurring within the saltwater intrusion zone of

12 the southern Everglades. Millero et al. (2001) have determined that phosphate adsorption onto

13 carbonate minerals decreases as salinity increases and attributed their results to the presence of

14 sulfate and bicarbonate ions. These anions may be competing with the phosphate ion for

15 exchange sites and may explain the nonconservative nature of sulfate upon mixing fresh

16 groundwater and surface seawater. The linear increase in TP concentration with salinity in the

17 brackish groundwaters suggests phosphorus may be desorbed from the aquifer materials with the 18 intruding seawater (Fig.8).

19 Groundwater discharge in the southern Everglades appears to be seasonal, occurring

20 dominantly during the dry season when excess sodium, chloride, and calcium is observed in

21 receiving surface waters. This seasonality in groundwater discharge was observed by others

22 (Top et al., 2001; Sutula et al., 2001), and is due to higher surface water levels in both the

23 Everglades and in Florida Bay in the summer wet season. The higher surface water levels result 
1 in either reducing groundwater discharge to near zero or even reversing the direction so that the

2 surface water recharges the groundwater. For instance, groundwater discharge in the regions of

3 Taylor Slough and C-111 basin have been estimated at $48 \mathrm{~cm} / \mathrm{yr}$ during the dry season, but

4 during the wet season the groundwater was recharged between 25 to $35 \mathrm{~cm} / \mathrm{yr}$, resulting in a

5 mean annual discharge of $8 \mathrm{~cm} / \mathrm{yr}$ (Sutula et al., 2001). This groundwater discharge value is

6 similar to the rate of 2 to $12 \mathrm{~cm} / \mathrm{yr}$ estimated for groundwater recharge in the upland regions of

7 ENP (Price \& Swart, In press).

8 Assuming an average TP value in the CGD of $1.5 \mu \mathrm{M}$, a CGD of $8 \mathrm{~cm} / \mathrm{yr}$ results in a

9 discharge flux of $0.12 \mathrm{mM} \mathrm{P} \mathrm{m}^{-2} \mathrm{yr}^{-1}$. This value is twice as high as earlier estimates of

10 groundwater input of $0.06 \mathrm{mM} \mathrm{P} \mathrm{m}^{-2} \mathrm{yr}^{-1}$ along Taylor Slough and the C-111 basin (Sutula et al.,

11 2001), however, those estimates were made without groundwater $P$ data. Assuming an extent of

12 seawater intrusion of $10 \mathrm{~km}$ inland along $75 \mathrm{~km}$ length of coastline extending from the C-111

13 basin to the western edge of Shark Slough, results in a CGD zone of $750 \mathrm{~km}^{2}$, and a flux of 2.8

14 metric tons of $\mathrm{P}$ to the surface water annually. This amount of $\mathrm{P}$ is equivalent to the amount of

15 phosphorus delivered by Taylor Slough ( $<2.6$ metric tons/yr) to Florida Bay. This amount of P,

16 however, is considerably less than the estimated 14 metric tons/yr of P delivered to the the 750

$17 \mathrm{~km}^{2}$ coastal zone via atmospheric inputs (Rudnick et al., 1999).

18 Despite the high concentrations of TP in the brackish groundwaters, only low TP values

$19(<0.5 \mu \mathrm{M})$ are detected in the overlying surface waters. These results suggest that the phosphorus

20 transported with the CGD is either removed from the surface water column quickly by biotic

21 processes (Gaiser et al., 2004) or is retained in the Everglades soils by sorption, particularly to

22 calcium carbonate particles (De Kanel \& Morse, 1978), clays (Zhou \& Li, 2001) and iron-oxides

23 (Chambers et al., 2001). Soils within the mangrove zone are indeed a sink for phosphorus as 
1 indicated by higher concentrations of phosphorus measured in shallow sediments $(2.5 \mathrm{~cm})$ within

2 the mangrove zone as opposed to freshwater upland sites (Chen \& Twilley, 1999). The high

3 concentrations of TP in the groundwater along with any sorbed to the soils is then available for

4 plant root uptake by the coastal mangroves.

5 The Everglades and Florida Bay are oligotrophic systems and extremely sensitive to

6 exogenous inputs of nutrients, particularly phosphorus (Fourqurean et al., 1992; Gaiser et al.,

7 2004). Phosphorus inputs from canals that drain the surrounding agricultural landscape have

8 been implicated as major drivers of biotic change of the Everglades ecosystem (Davis, 1994;

9 Noe et al., 2003). Along the southern margin of the Florida peninsula, the freshwater,

10 oligotrophic Everglades and the marine oligotrophic Florida Bay ecosystems are separated by an

11 often lush mangrove forest. The highly productive mangrove forest separating the two nutrient-

12 limited ecosystems seems to require a phosphorus source that is independent of the mixing of

13 Everglades surface water and the marine waters of Florida Bay. We hypothesis that the high

14 productivity of the mangrove forest along the coastal Everglades maybe supported by $\mathrm{P}$

15 delivered by CGD.

16 
1 Acknowledgements: We thank Tiffany McKelvey, Gordon Anderson, Mark Stewart, and

2 Gustavo Rubio for their help in the field, and the FIU seagrass lab for their help in the laboratory.

3 This project was made possible with contributions from the FIU Foundation and was supported

4 by the Florida Coastal Everglades LTER program funded by the US National Science

5 Foundation (DEB-9910514) and the NSF REU program. This is contribution number \# of the

6 Southeast Environmental Research Center at FIU. 


\section{References:}

2 Armitage, A. R., T. A. Frankovich \& J. W. Fourqurean, This issue. Variable responses within 3 epiphytic and benthic microalgal communities to nutrient enrichment. Hydrobiologia.

4 Armitage, A. R., T. A. Frankovich, K. L. J. Heck \& J. W. Fourqurean, 2005. Experimental 5 nutrient enrichment causes complex changes in seagrass, microalgae, and macroalgae 6 community structure in Florida Bay. Estuaries, 28:422-434.

7 Back, W., B. B. Hanshaw, J. S. Herman \& J. N. Van Driel, 1986. Differential dissolution of a 
1 Davis, S. M., 1994. Phosphorus inputs and vegetation sensitivity in the Everglades. In Davis, S.

2 M. \& J. C. Odgen (eds), Everglades: The ecosystem and its restoration. St. Lucie Press, $3 \quad$ Boca Rotan: $357-378$.

4 De Kanel, J. \& J. W. Morse, 1978. The chemistry of orthophosphate uptake from seawater onto calcite and aragonite. Geochimica et Cosmochimica Acta, 42:1335-1340.

6 Du Commun, J., 1828. On the causes of fresh water springs, fountains, etc. American Journal of $7 \quad$ Science, $14: 174-176$

8 Fish, J. E. \& M. Stewart. 1991. Hydrogeology of the surficial aquifer system, Dade County,

9 Florida.: USGS Water-Resources Investigations Report 90-4108.

10 Fitterman, D. V., M. Deszcz-Pan \& C. E. Stoddard. 1999. Results of Time-Domain

11 Electromagnetic Soundings in Everglades National Park, Florida.. Denver: USGS Open-

$12 \quad$ File Report 99-426.

13 Fourqurean, J. W., G. V. N. Powell \& J. C. Zieman, 1992. Relationships bewteen porewater

14 nutrients and seagrasses in a subtropical carbonate environment. Marine Biology, 114:57$15 \quad 65$.

16 Fourqurean, J. W. \& M. B. Robblee, 1999. Florida Bay: A History of Recent Ecological $17 \quad$ Changes. Estuaries, 22:345-357.

18 Gaiser, E. E., L. J. Scinto, J. H. Richards, K. Jayachandran, D. L. Childers, J. C. Trexler \& R. D. Jones, 2004. Phosphorous in periphyton mats provides the best metric for detecting lowlevel P enrichment in an oligotrophic wetland. Water Research, 38:507-516.

21 Ghyben, B., W., 1888. Nota in verband met de vorrgenomen putboring nabij Amsterdam:

22 Tijdschrift van Let Koninklijk Institute van Ingeneiurs, The Hague:8-22. 
1 Gil, M., A. R. Armitage \& J. W. Fourqurean, This issue. Nutrients alter epifaunal density and species composition in a subtropical seagrass bed. Hydrobiologia.

3 Herzberg, B., 1901. Die Wasserverzorgung einiger Nordseebaden. J. Gasbelechntung und

$4 \quad$ Wasserversorgung, 44:815-819.

5 Hittle, C., E. Patino \& M. Zucker. 2001. Freshwater Flow from Estuarine Creeks into

$6 \quad$ Northeastern Florida Bay, USGS Water Resources Investigations Report 01-4164.

7 Klein, H. \& B. G. Waller. 1985. Synopsis of saltwater intrusion in Dade County, Florida,

8 through 1984. USGS Water-Resources Investigations Report 85-410.

9 Kohout, F. A., 1960. Cyclic Flow of Salt Water in the Biscayne Aquifer of Southeastern Florida. 10 Journal of Geophysical Research, 65:2133-2141.

11 Kohout, F. A. 1964. Flow of freshwater and saltwater in the Biscayne aquifer of the Miami area, 12 Florida.: USGS Water-Supply Paper 1613-C, C12-C32.

13 Konikow, L. F. \& T. E. Reilly, 1999. Seawater intrusion in the United States. In Bear, J., Cheng,

14 Soerk, Ouazar \& Herrera (eds), Seawater intrusion in coastal aquifers: Concepts,

15 methods, and practices. Kluwar Academic Publishers, Dordrecht, The Netherlands: 46316506.

17 Light, S. S. \& J. W. Dineen, 1994. Water control in the Everglades: A historical perspective. In

18 Davis, S. M. \& J. C. Odgen (eds), Everglades: The ecosystem and its restoration. St.

19 Lucie Press, Delray Beach, FL: 47-84.

20 Millero, F., F. Huang, X. Zhu, X. Liu \& J.-Z. Zhang, 2001. Adsorption and Desorption of

21 Phosphate on Calcite and Aragonite in Seawater. Aquatic Geochemistry, 7:33-56.

22 Moore, W. S., 1999. The subterranean estuary: a reaction zone of ground water and sea water.

23 Marine Chemistry, 65:111-125. 
1 Noe, G. B., L. J. Scinto, J. Taylor, D. L. Childers \& R. D. Jones, 2003. Phosphorous cycling and partitioning in an oligotrophic Everglades wetland ecosystem: a radiostope tracing study. Freshwater Biology, 48:1993-2008.

Parker, G. G., G. E. Gerguson, S. K. Love \& others. 1955. Water resources of Southeastern Florida with special reference to geology and groundwater of the Miami areas. pp. 965: USGS Water-Supply Paper 1255.

Price, R. M. 2001. Geochemical determinations of groundwater flow in Everglades National Park. In: Marine Geology and Geophysics, pp. 307. Miami: University of Miami.

Price, R. M. \& J. S. Herman, 1991. Geochemical investigation of salt-water intrusion into a coastal carbonate aquifer; Mallorca, Spain. GSA Bulletin, 103:1270-1279.

Price, R. M. \& P. K. Swart, In press. Geochemical indications of groundwater recharge into the Surficial Aquifer System: Everglades National Park. GSA Bulletin Special Publication "Karst Geomorphology, Hydrology, \& Geochemistry-A Tribute Volume to Derek C. Ford and William B. White".

Price, R. M., Z. Top, J. D. Happell \& P. K. Swart, 2003. Use of tritium and helium to define groundwater flow conditions in Everglades National Park. Water Resources Research, 39:1267.

Reese, R. S. \& K. J. Cunningham. 2000. Hydrogeology of the Gray Limestone Aquifer in Southern Florida. pp. 1-78: USGS Water-Resources Investigation Report 99-4213.

Rudnick, D., Z. Chen, D. L. Childers, J. N. Boyer \& T. D. I. Fontaine, 1999. Phosphorus and Nitrogen Inputs to Florida Bay: The Importance of the Everglades Watershed. Estuaries, 22:398-416. 
1 Sivan, O., Y. Yechieli, B. Herut \& B. Lazar, 2005. Geochemical evolution and timescale of seawater intrusion into the coastal aquifer of Isreal. Geochimica et Cosmochimica Acta, 69:579-592.

4 Solorzano, L. \& J. H. Sharp, 1980. Determination of total dissolved phosphorus and particulate phosphorus in natural waters. Limnology and Oceanography, 25:754-758.

6 Sonenshein, R. S. 1997. Delineation and extent of saltwater intrusion in the Biscayne Aquifer,

7 Eastern Dade County, Florida. USGS Water-Resour. Invest. Report 96-4285.

8 Sonenshein, R. S. \& E. J. Koszalka. 1996. Trends in water-table altitude (1984-93) and saltwater

9 intrusion (1974-93) in the Biscayne aquifer, Dade County, Florida. pp. 2 sheets: USGS

$10 \quad$ Open-File Report 95-705.

11 Sutula, M., J. W. Day, J. Cable \& D. Rudnick, 2001. Hydrological and nutrient budgets of 12 freshwater and estuarine wetlands of Talyor Slough in Southern Everglades, Florida 13 (U.S.A.). Biogeochemistry, 56:287-213.

14 Top, Z., L. E. Brand, R. D. Corbett, W. Burnett \& J. P. Chanton, 2001. Helium and Radon as 15 Tracers of Groundwater Input Into Florida Bay. Journal of Coastal Research, 17:859-868.

16 Younger, P. L., 1996. Submarine groundwater discharge. Nature, 382:121-122.

17 Zhou, M. \& Y. Li, 2001. Phosphorus-Sorption characteristics of calcareous soils and limestone 18 from the southern Everglades and Adjacent Farmlands. Soil Scienctists Society of 19 American Journal, 65:1404-1412. 
Table 1. Summary of phosphorus concentrations in groundwater and surface water.

\begin{tabular}{|c|c|c|c|c|c|c|}
\hline $\begin{array}{r}\text { Site Name } \\
(\mathrm{SW}=\text { Surface water })\end{array}$ & $\begin{array}{c}\text { Sampling } \\
\text { Date }\end{array}$ & $\begin{array}{c}\text { Depth } \\
(\mathbf{m})\end{array}$ & $\begin{array}{c}\text { Temp. } \\
\left({ }^{\circ} \mathrm{C}\right)\end{array}$ & pH & $\begin{array}{c}\text { Salinity } \\
\text { (psu) }\end{array}$ & $\begin{array}{r}\text { Total P } \\
(\mathbf{u M})\end{array}$ \\
\hline SH-1 SW & 20-Jun-03 & & 31.1 & 7.35 & 0.0 & 0.31 \\
\hline LO1 SW & 18-Jul-03 & & 30.6 & 7.53 & 0.0 & 0.21 \\
\hline CH1 SW & 18-Jul-03 & & 35.5 & 7.38 & 0.0 & 0.45 \\
\hline UPPER TAYLOR RIVER SW & 12-Aug-03 & & 30.2 & 7.46 & 0.2 & 0.27 \\
\hline E-146 SW & 15-Aug-03 & & 28.3 & 7.32 & 0.0 & 0.21 \\
\hline RB-1 SW & 19-Aug-03 & & 28.4 & 7.00 & 0.0 & 0.33 \\
\hline CANEPATCH SW & 19-Aug-03 & & 29.3 & 7.02 & 0.0 & 0.16 \\
\hline TARPON BAY SW & 19-Aug-03 & & 30.6 & 7.30 & 0.6 & 0.22 \\
\hline E-130 SW & 25-Nov-03 & & 24.9 & 7.30 & 0.0 & 0.15 \\
\hline \multicolumn{7}{|l|}{ (GW=Groundwater) } \\
\hline SH-1 GW & 20-Jun-03 & 2.5 & 25.9 & 6.37 & 0.06 & 0.88 \\
\hline G-3302A & 1-Aug-03 & 4.3 & 26.5 & 7.06 & 0.0 & 0.75 \\
\hline E-130 SHALLOW & 25-Nov-03 & 3 & 26.2 & 7.01 & 0.0 & 0.12 \\
\hline E-130 DEEP & 25-Nov-03 & 15.2 & 25.9 & 6.96 & 0.0 & 0.22 \\
\hline CH1 GW & 18-Jul-03 & 2.5 & 26.6 & 6.81 & 29.9 & 2.34 \\
\hline UTR DEEP GW & 12-Aug-03 & 6.7 & 27.4 & 6.54 & 28.1 & 1.45 \\
\hline UTR SHALLOW GW & 12-Aug-03 & 0.6 & 28.7 & 6.54 & 27.5 & 2.12 \\
\hline E-146 SHALLOW GW & 15-Aug-03 & 4.6 & 26.2 & 6.65 & 10.6 & 0.5 \\
\hline E-146 DEEP GW & 15-Aug-03 & 7.6 & 25.9 & 6.68 & 12.6 & 0.63 \\
\hline E-146-27 GW & 15-Aug-03 & 8.4 & 25.8 & 6.58 & 16.3 & 0.75 \\
\hline RB-1 GW & 19-Aug-03 & 6.7 & 25.1 & 6.67 & 3.4 & 0.37 \\
\hline CANEPATCH GW & 19-Aug-03 & 15.5 & 25.4 & 6.84 & 15.2 & 1.9 \\
\hline TARPON BAY GW & 19-Aug-03 & 19.8 & 26.1 & 6.8 & 20.8 & 2.25 \\
\hline LO1 GW & 18-Jul-03 & 3 & 27.7 & 6.57 & 7.6 & 0.97 \\
\hline
\end{tabular}




\section{$1 \quad$ List of Figures}

Figure 1. a) Submarine groundwater discharge (SGD) and b) coastal groundwater discharge (CGD).

Figure 2. Map of south Florida and study area.

Figure 3. Extent of seawater intrusion into the shallow portion $(<28 \mathrm{~m})$ of the SAS. Contours represent salinity with a 5 psu contour interval. Circles with crosses represent a cluster of one to four groundwater wells completed in the SAS.

Figure 4. Salinity of surface water in a) the C-111 canal; b) Taylor Slough and C-111 basin; and c) Shark Slough. See Fig. 3 for station locations.

Figure 5. Salinity of groundwater in wells a) along the C-111 canal; b) in Taylor Slough and the C-111 basin; and c) in Shark Slough. Legend refers to the well name as shown on Fig. 3 and well depth in parenthesis.

Figure 6. Piper diagram depicting major ion chemistry at EP8A in the southern Everglades. During most of the sampling events, surface waters (black dots) were a $\mathrm{Ca}^{2+}-\mathrm{HCO}_{3}{ }^{-}$type water. Groundwater (square) is dominated by $\mathrm{Na}^{+}$and $\mathrm{Cl}^{-}$ions indicative of seawater intrusion. Surface waters had a brackish signature (gray triangles) during the months indicated in the legend. See Fig. 3 for site location. 
1 Figure 7. Mean calcium (mM) in groundwaters (open circles) and surface waters (solid diamonds) relative to a seawater mixing line. Error bars represent \pm one standard error.

4 Figure 8. Elevated calcium concentrations in Everglades surface waters relative to surface

11 Figure 9. Total phosphorus $(\mu \mathrm{M})$ in groundwater samples (solid circles) increase linearly with salinity, and are higher than the mean TP of surface waters of the Everglades (open square), eastern Florida Bay (open cross), and the Gulf of Mexico (solid triangle). 

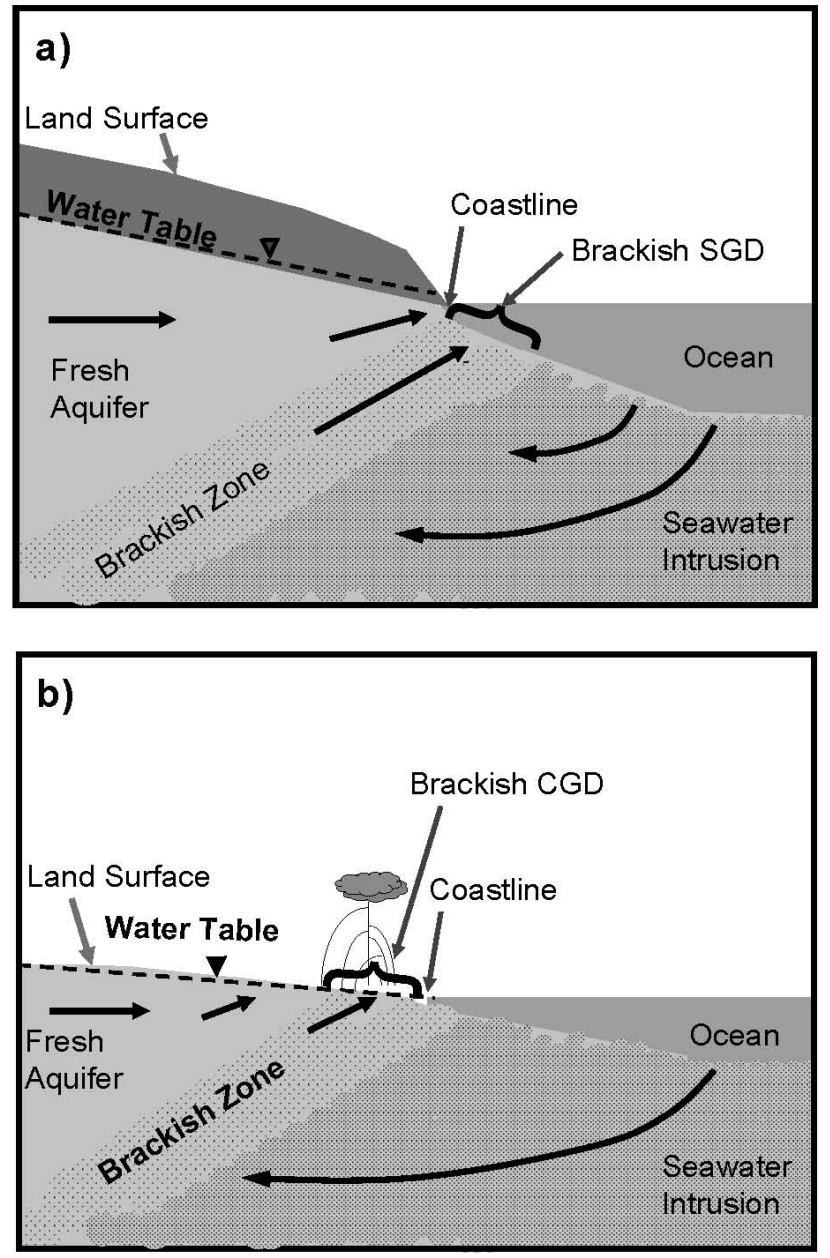

Price et al. Fig. 1 


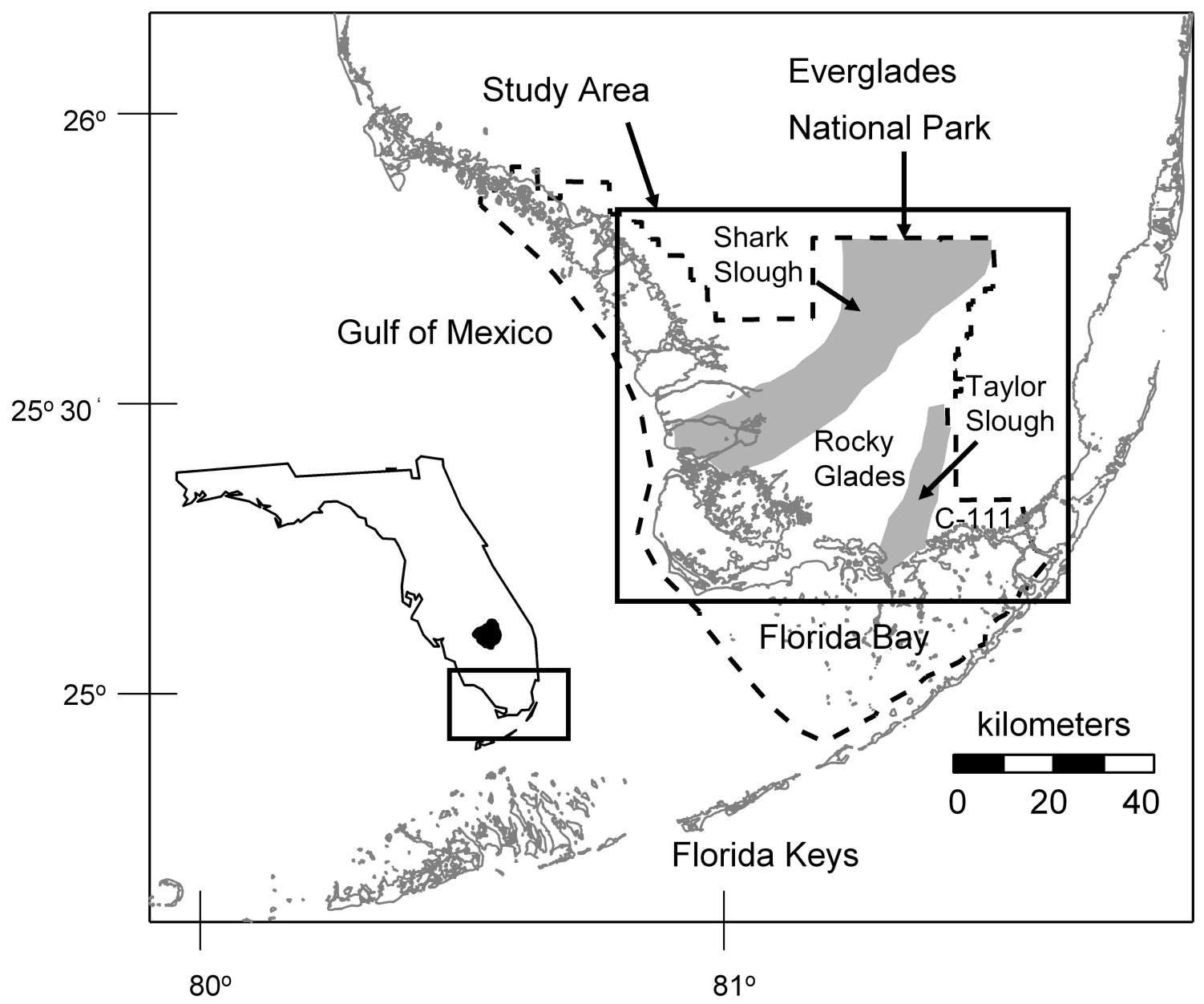

2

18 Price et al. Fig 2 


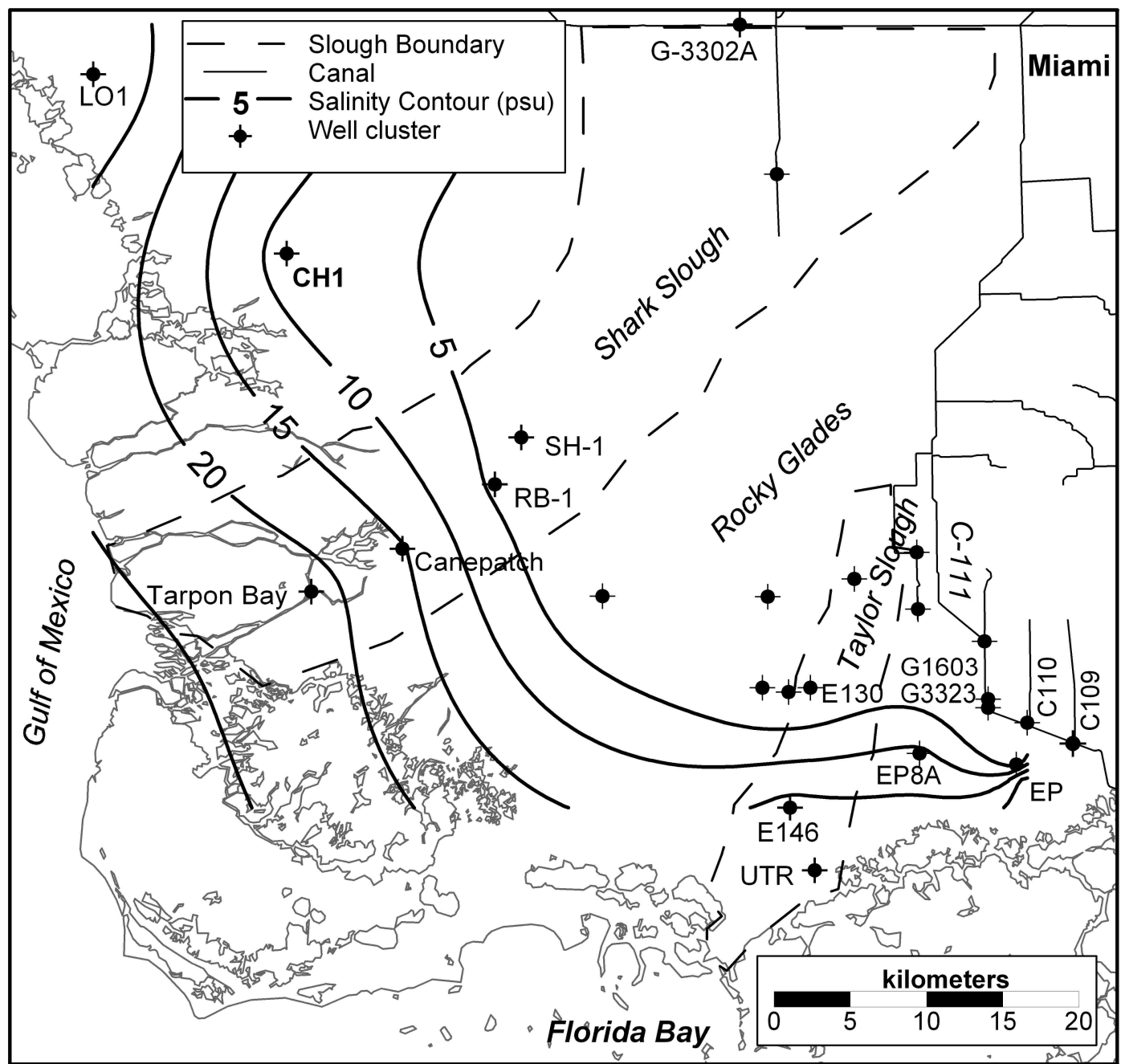

Price et al Fig. 3 


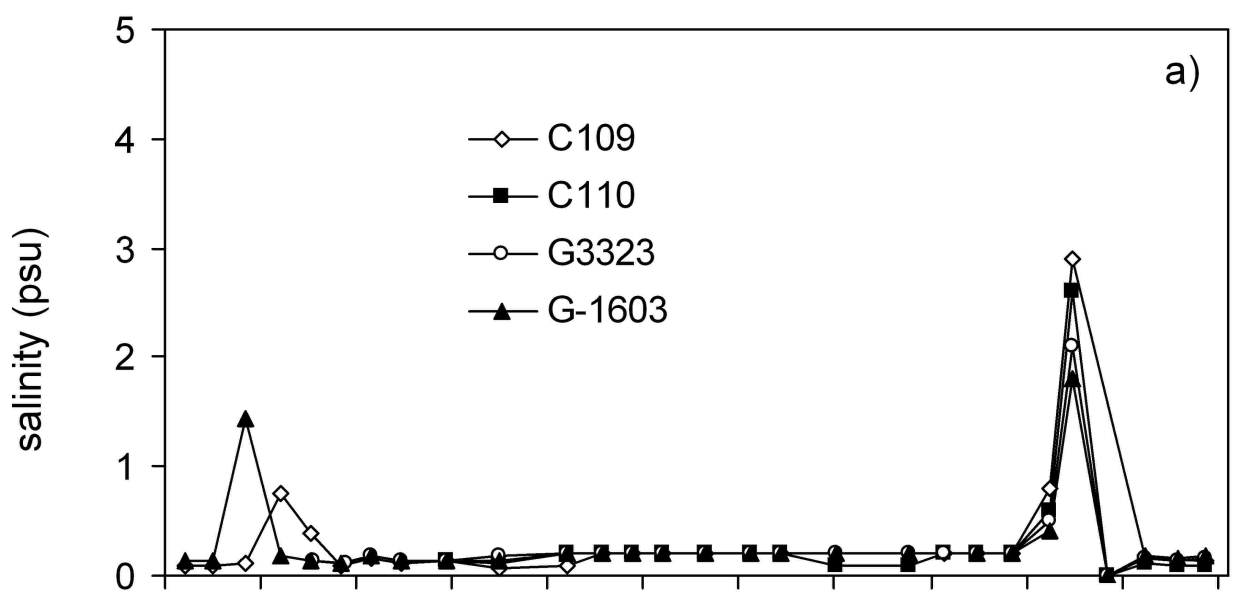

Jan- Apr- Jul- Oct- Jan- Apr- Jul- Oct- Dec- Mar- Jun- Sep$\begin{array}{llllllllllll}97 & 97 & 97 & 97 & 98 & 98 & 98 & 98 & 98 & 99 & 99 & 99\end{array}$
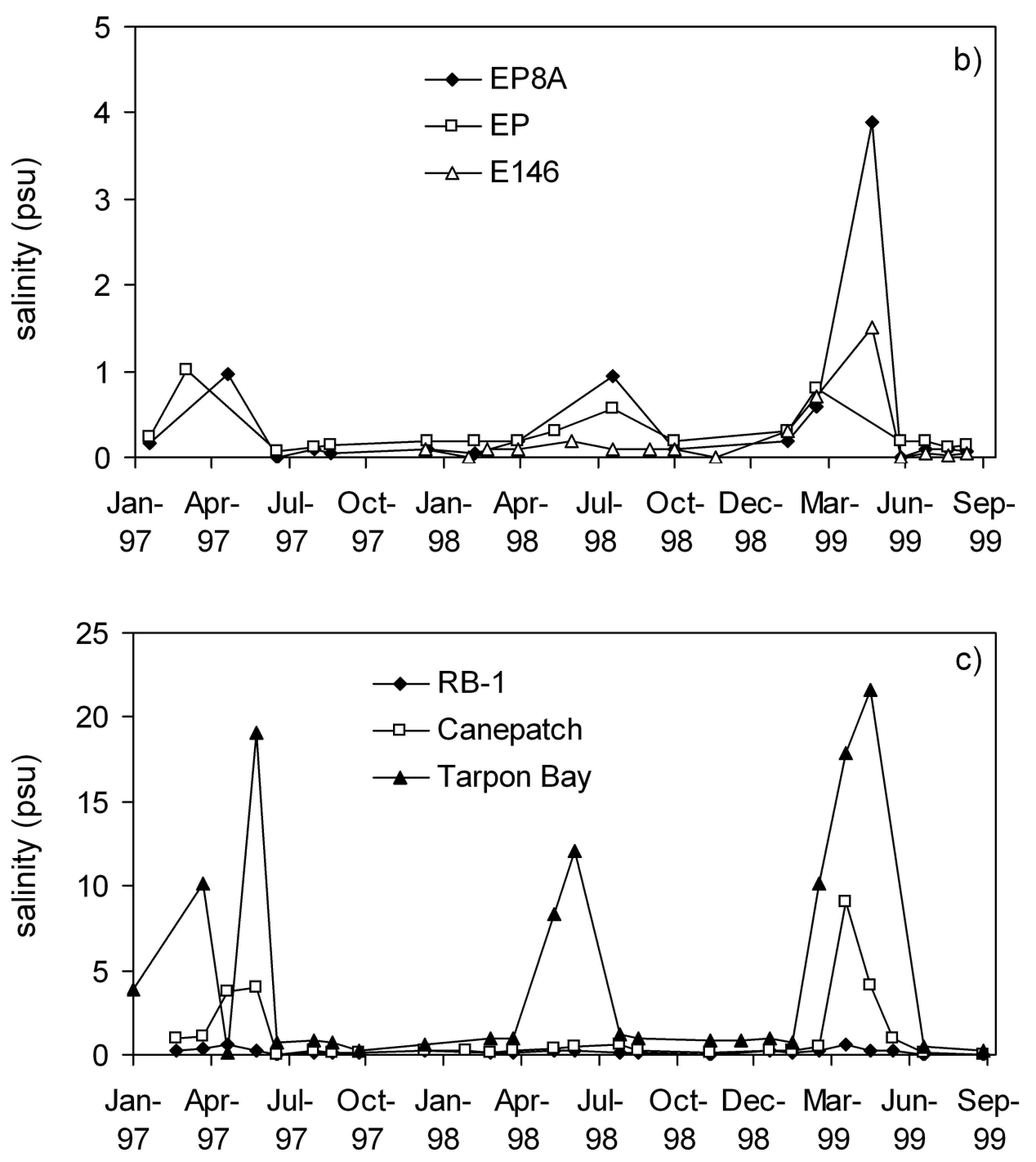

Price Fig. 4 


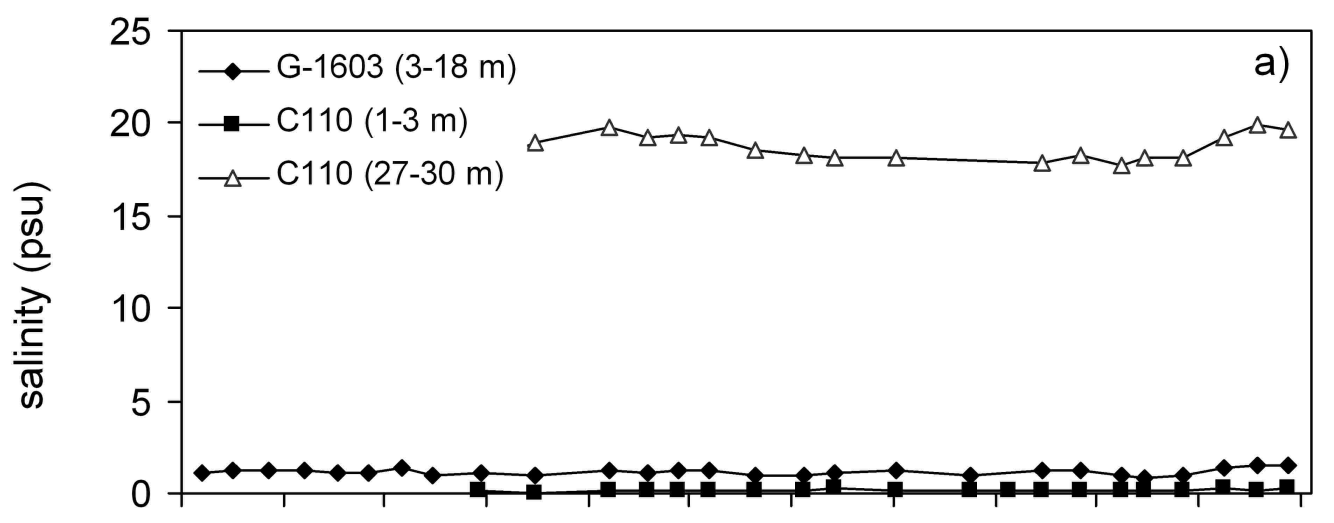

Jan- Apr- Jul- Oct- Jan- Apr- Jul- Oct- Dec- Mar- Jun- Sep$\begin{array}{llllllllllll}97 & 97 & 97 & 97 & 98 & 98 & 98 & 98 & 98 & 99 & 99 & 99\end{array}$

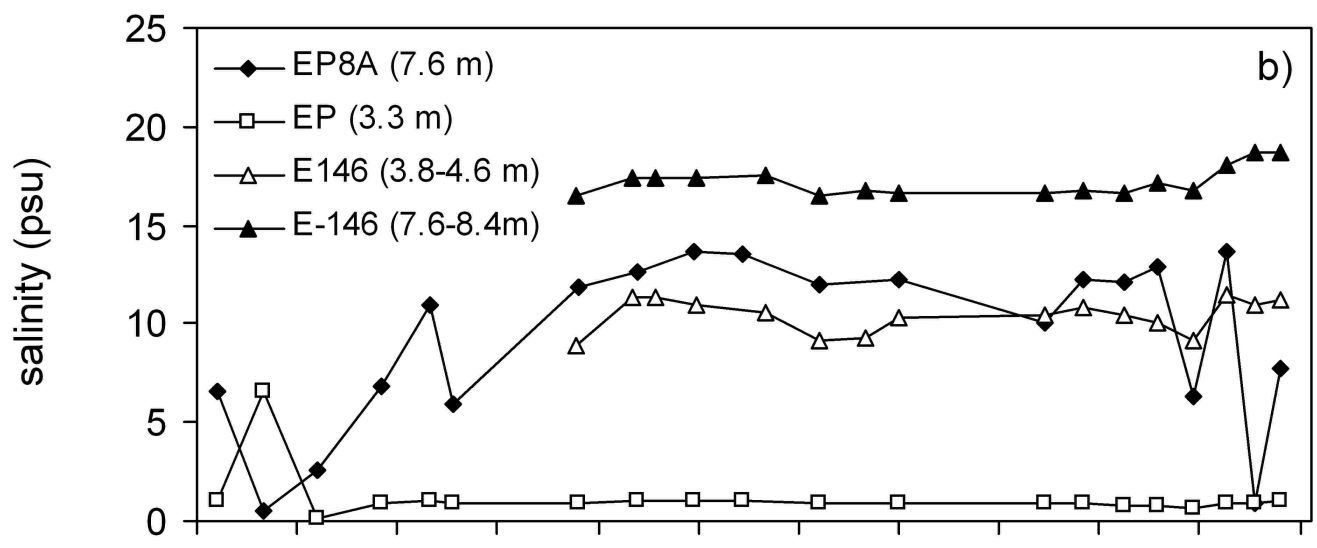

Jan- Apr- Jul- Oct- Jan- Apr- Jul- Oct- Dec- Mar- Jun- Sep$\begin{array}{llllllllllll}97 & 97 & 97 & 97 & 98 & 98 & 98 & 98 & 98 & 99 & 99 & 99\end{array}$

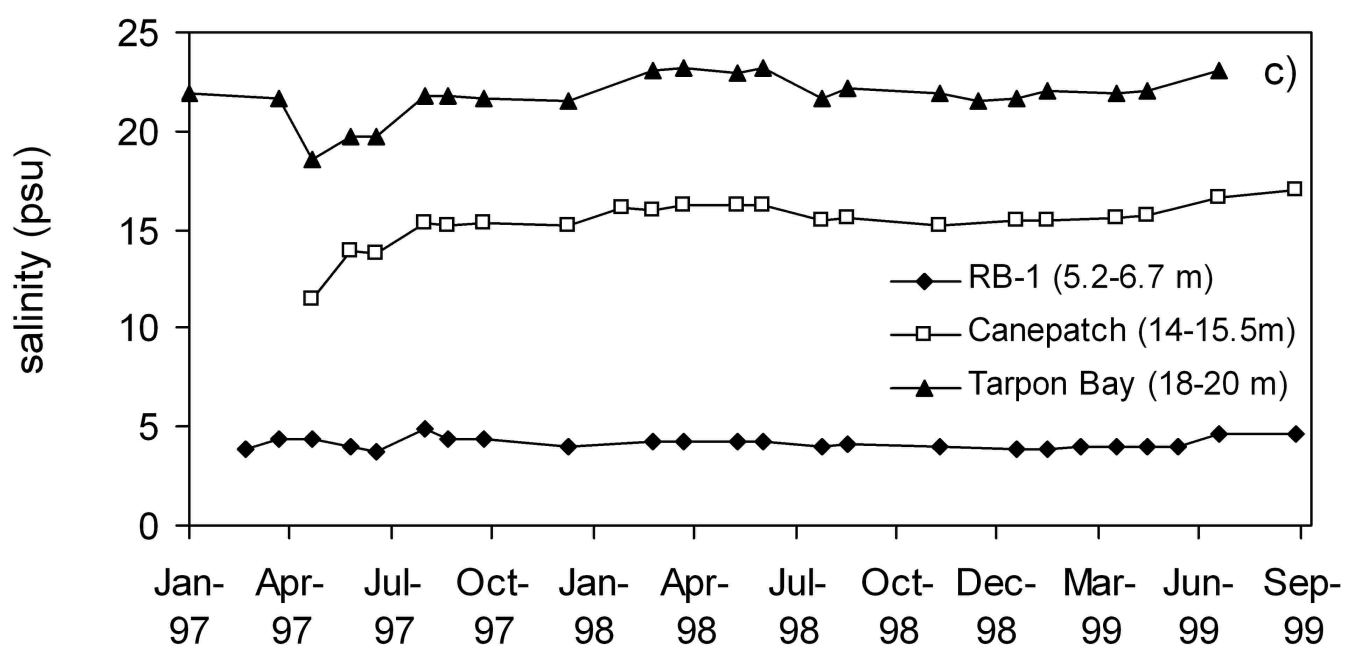

Price et a. Fig. 5 


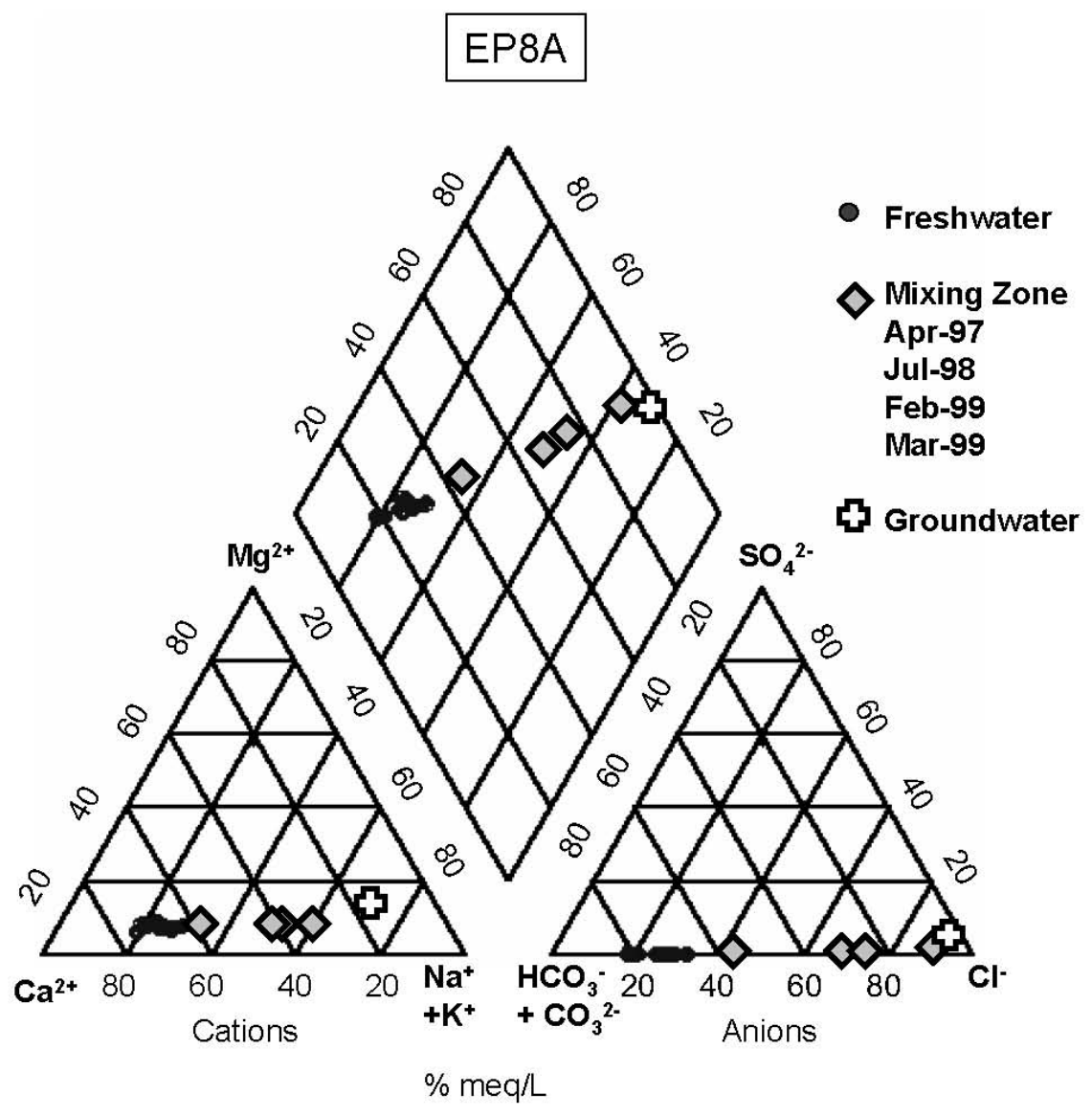

17 Price et al. Fig. 6 


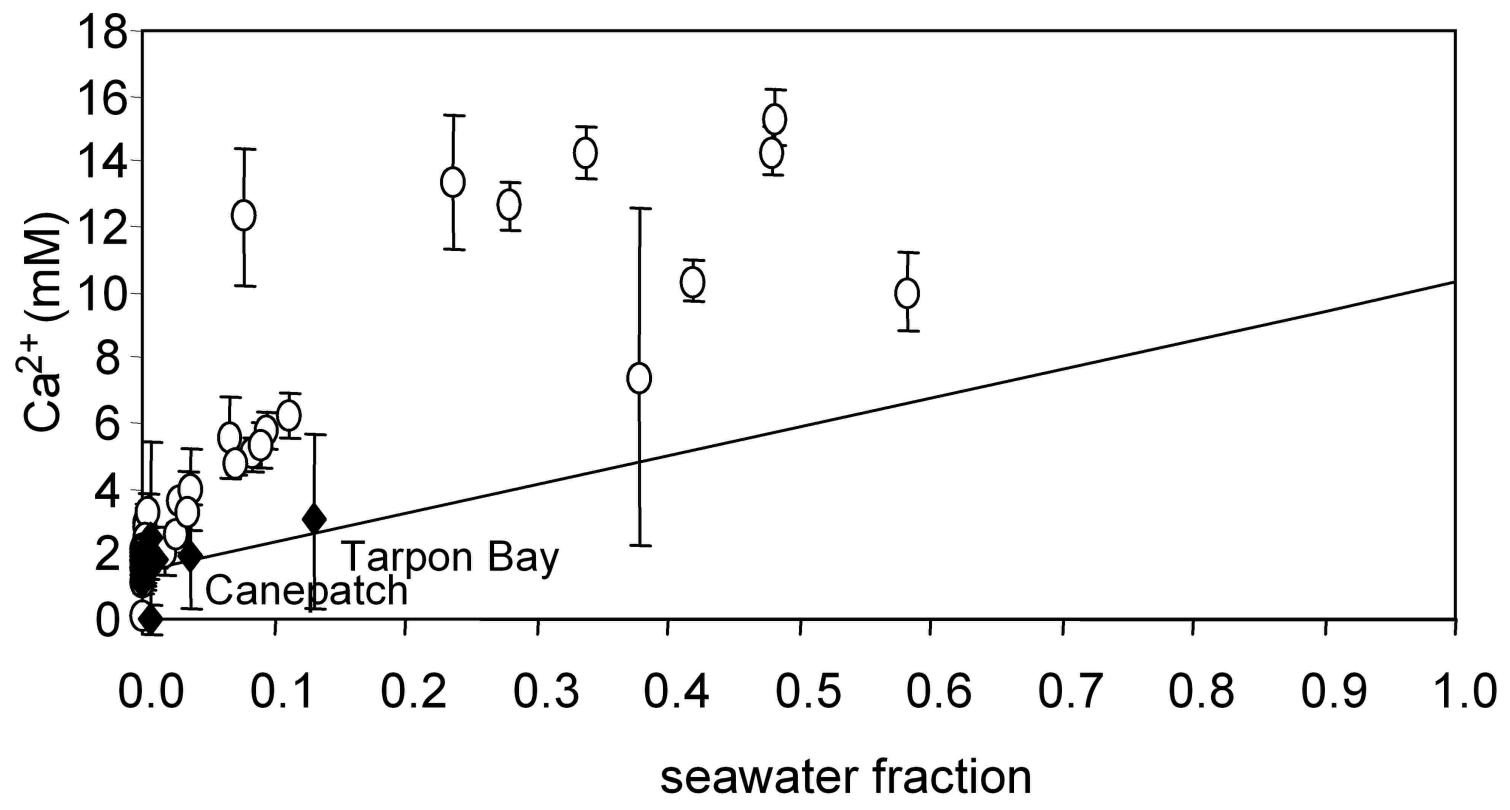

1

21 Price et al. Fig. 7 


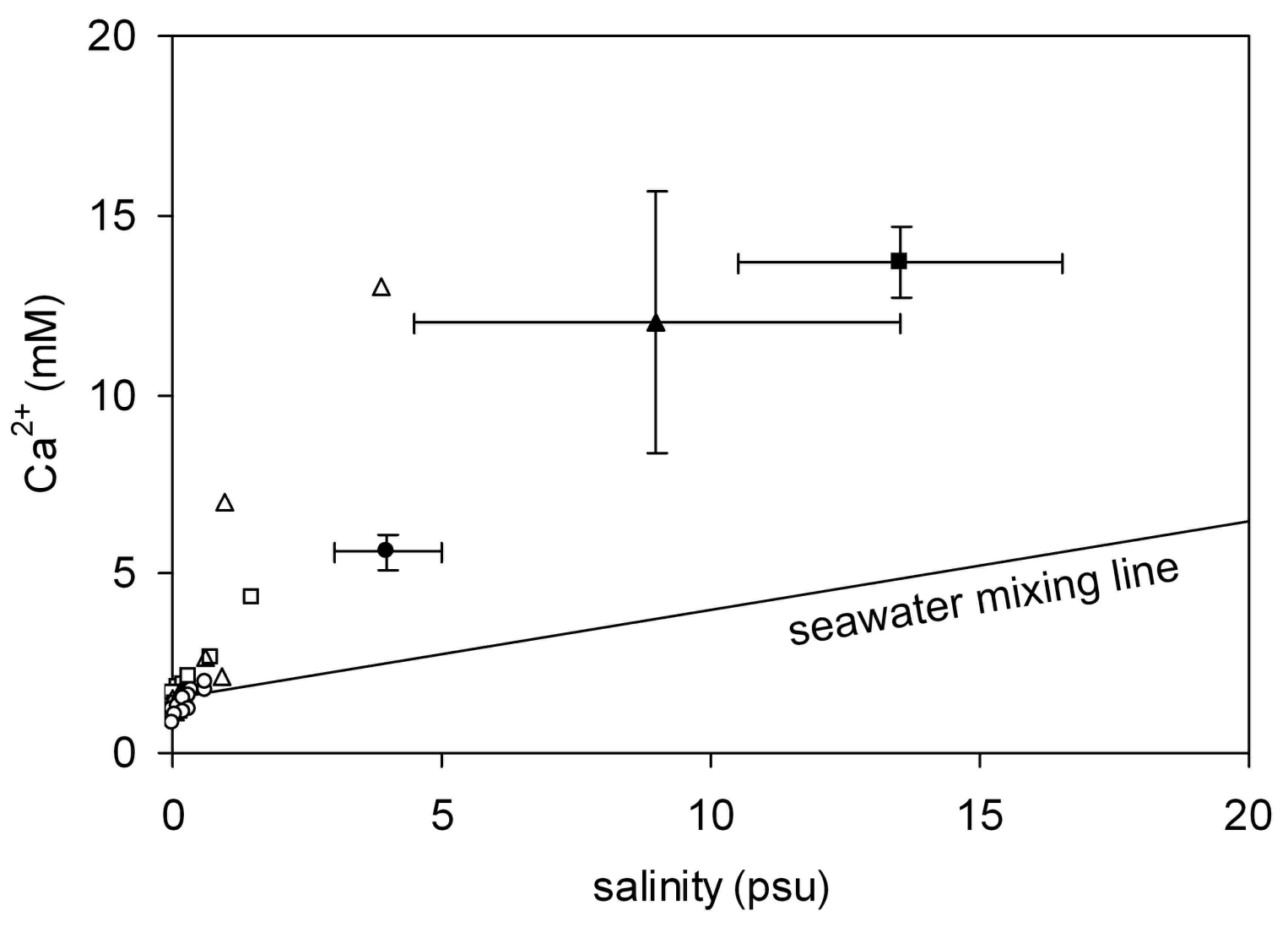

1

3

4

5

6

14

15

16

17

18 Price et al. Fig. 8 


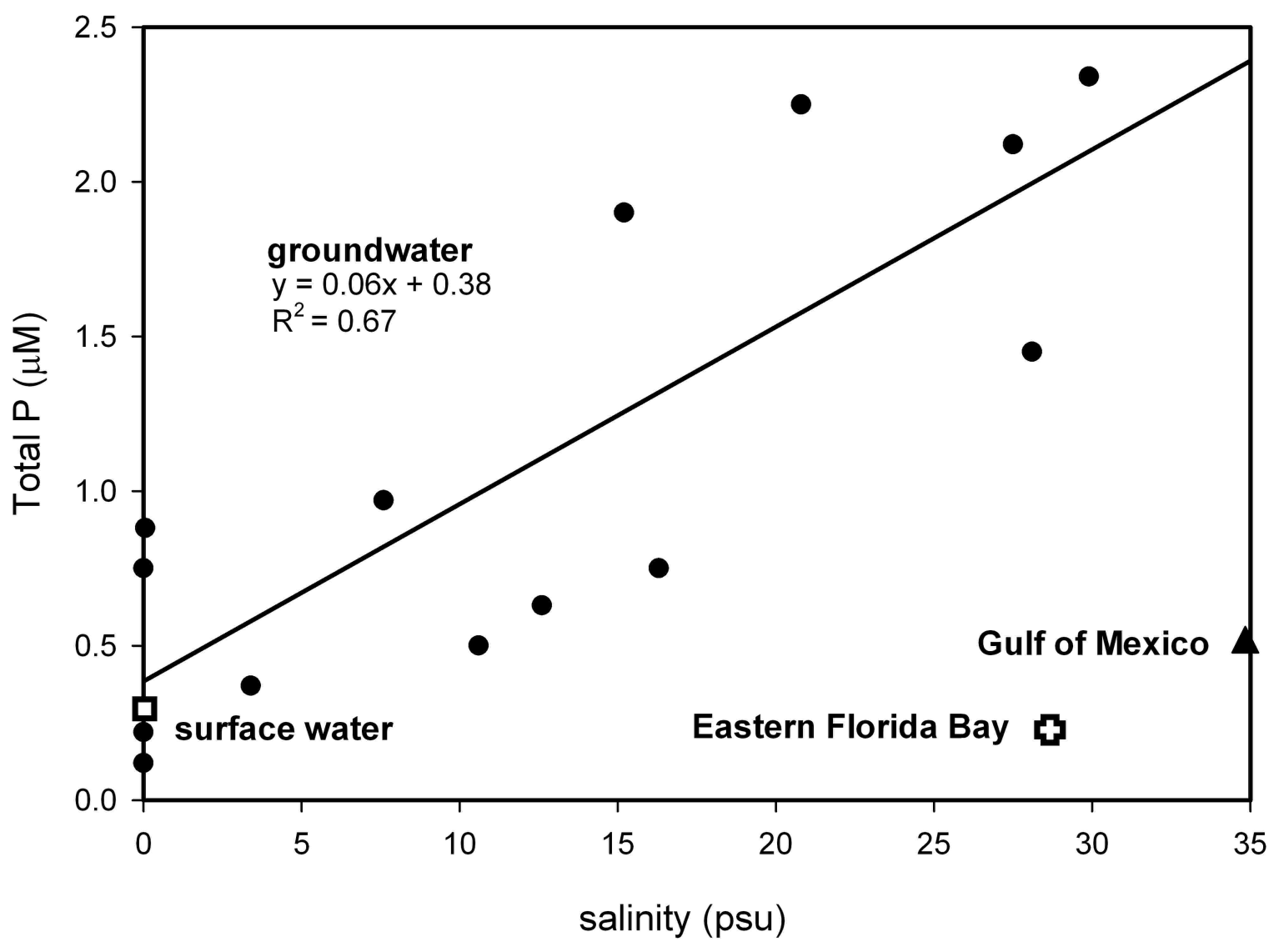

2

3

4

5

Price et al. Fig. 9. 